\title{
Uji Toksisitas Akut Ekstrak Metanol Kulit Buah Jeruk Sambal (Citrus microcarpa Bunge) Terhadap Larva Artemia salina L. Dengan Metode Brine Shrimp Lethality Test (BSLT)
}

\section{The Cytotoxic Activity Of Methanol Extract Of Jeruk Sambal (Citrus microcarpa Bunge) Peel Using The Brine Shrimp Lethality Test /BSLT (Artemia salina L.) Method}

\author{
Ratna Widyasari *), Dina Yuspitasari, Wilda Wildaniah, Rosi Cahayuni \\ Wahida \\ Akademi Farmasi Yarsi Pontianak \\ Jl. Panglima A'im Pontianak
}

Submitted: 28-07-2018

Reviewed: $10-08-2018$

Accepted: 24-08-2018

\begin{abstract}
ABSTRAK
Tanaman jeruk sambal (Citrus microcarpa Bunge) merupakan salah satu tanaman yang banyak terdapat di Kalimantan Barat. Kulit buah jeruk sambal mempunyai aktivitas antioksidan kuat dan aktivitas antimikroba, hal ini berkaitan erat dengan kandungan senyawa metabolit sekunder yaitu flavonoid, alkaloid dan polifenol, dimana senyawa ini berpotensi sitotoksik. Tujuan dari penelitian ini adalah untuk mengetahui apakah ekstrak metanol kulit jeruk sambal bersifat sitotoksik dengan metode Brine Shrimp Lethality Test (BSLT) dan mengetahui nilai $\mathrm{LC}_{50}$ yang dihasilkan. Penelitian eksperimental ini menggunakan ekstrak metanol kulit jeruk sambal dengan pembagian konsentrasi $1000 \mu \mathrm{g} / \mathrm{ml}, 750 \mu \mathrm{g} / \mathrm{ml}, 500$ $\mu \mathrm{g} / \mathrm{ml}, 250 \mu \mathrm{g} / \mathrm{ml}, 100 \mu \mathrm{g} / \mathrm{ml}$, dan $0 \mu \mathrm{g} / \mathrm{ml}$ dimana pada masing-masing konsentrasi diletakkan 10 ekor larva Artemia salina L. Data kematian larva dikumpulkan dan dianalisis dengan metode analisis probit. Berdasarkan hasil dari analisis regresi linier menunjukkan nilai $\mathrm{LC}_{50}$ dari ekstrak metanol kulit jeruk sambal adalah $234,42 \mu \mathrm{g} / \mathrm{ml} .$. Hasil penelitian ini menunjukan bahwa ekstrak metanol kulit jeruk sambal bersifat sitotoksik yang ditunjukkan dengan harga $\mathrm{LC}_{50}<1000 \mu \mathrm{g} / \mathrm{ml}$.
\end{abstract}

Kata kunci : Kulit jeruk sambal (Citrus microcarpa Bunge), Brine Shrimp Lethality Test (BSLT), $\mathrm{LC}_{50}$

\begin{abstract}
"Jeruk sambal" (Citrus microcarpa Bunge) is one of many plants in West Kalimantan. Citrus peel has strong antioxidant activity and antimicrobial activity, that is closely related to the content of secondary metabolite compounds namely flavonoids, alkaloids and polyphenols, that could be potentially cytotoxic. The purpose of this study is to know cytotoxic activity and the $\mathrm{LC}_{50}$ the methanol extract of "jeruk sambal" peel. The study used Brine Shrimp Lethality Test (BSLT) method with the concentration of the extract constitutively are $1000 \mu \mathrm{g} / \mathrm{ml}, 750 \mu \mathrm{g} / \mathrm{ml}, 500 \mu \mathrm{g} / \mathrm{ml}, 250 \mu \mathrm{g} / \mathrm{ml}, 100 \mu \mathrm{g} / \mathrm{ml}$ and $0 \mu \mathrm{g} / \mathrm{ml}$, that were added to 10 larvae of Artemia salina L. Data of larvas mortality was collected and analyzed by probit analysis method. Based on the result of linear regression analysis showed that $\mathrm{LC}_{50}$ values of methanol extract of "jeruk sambal" peel was $234,42 \mu \mathrm{g} / \mathrm{ml}$. The results of
\end{abstract}


this study indicate that the methanol extract of "jeruk sambal" peel is cytotoxic indicated by the price of $\mathrm{LC}_{50}$ less than $1000 \mu \mathrm{g} / \mathrm{ml}$.

Keywords: "Jeruk sambal" (Citrus microcarpa Bunge) peel, Brine Shrimp Lethality Test (BSLT), $\mathrm{LC}_{50}$

\section{Penulis korespondensi:}

Ratna Widyasari

Akademi Farmasi Yarsi Pontianak

Jl. Panglima A'im Pontianak

Email: Sharee_300302@yahoo.co.id, No.Hp 08122629720

\section{PENDAHULUAN}

Di Indonesia, pemanfaatan bahan alam sebagai obat tradisional akhir-akhir ini cenderung meningkat, bahkan beberapa bahan alam telah diproduksi secara pabrikasi dalam skala besar dikarenakan bahan baku obat tradisional mudah diperoleh. Setiap bahan alam sebelum menjadi sediaan fitofarmaka harus melewati beberapa tahapan meliputi uji farmakologi eksperimental, uji toksisitas, uji klinis, uji kualitas dan pengujian lain sesuai persyaratan yang berlaku demi menjamin keamanan masyarakat dalam mengkonsumsinya (Tekha, 2015).

Salah satu tanaman yang biasa dimanfaatkan sebagai obat tradisional di Kalimantan Barat adalah tanaman jeruk sambal (Citrus microcarpa Bunge). Jeruk sambal merupakan satu diantara jenis tanaman yang buahnya biasa dikonsumsi dalam bentuk jus dan digunakan sebagai bumbu masak, sedangkan kulitnya jarang dikonsumsi namun dapat digunakan sebagai pelengkap masakan tertentu. Jeruk ini mengandung asam sitrat yang diketahui mampu mencerahkan warna pada resin komposit karena mengandung gugus $\mathrm{OH}$ yang berpotensi menjadi oksidator yang kuat. Menurut Cheong tahun 2013 jeruk sambal mengandung asam sitrat dan kandungannya banyak ditemukan pada jeruk yang matang. Jeruk ini juga digunakan sebagai obat untuk menjaga daya tahan tubuh, obat hipertensi, kudis dan gangguan paru-paru (Sibilang, 2017).

Kulit buah jeruk sambal memiliki aktivitas antioksidan. Adanya aktivitas antioksidan ini terhadap ekstrak metanol dikarenakan adanya senyawa metabolit sekunder yaitu senyawa flavonoid, alkaloid dan polifenol (Wulandari, 2013).

Menurut Jamal tahun 2000, kulit buah jeruk sambal juga mengandung sekitar 1,20\% minyak atsiri dengan $B$-sitronelol, (R)-(+) sitroneial, Ppinena, D-limonena, 4-metil-1-(1metietil)-3-sikloheksen-1-ol, $\beta$-linalool, $\alpha$-terpineol, $\alpha$-farnesena, $\beta$-sitral, L-Isopulegol dan cis-linalil oksida sebagai komponen utama. Minyak atsiri kulit jeruk sambal sensitif terhadap bakteri gram positif Staphylococcus epidermidis, Staphylococcus aureus dibanding bakteri gram negatif (E. Coli, Salmonella entritidis).

Aktivitas antimikroba dan antioksidan ini erat kaitannya dengan toksisitas tanaman dan diketahui toksisitas tanaman berkaitan erat dengan senyawa-senyawa metabolit sekunder yang ada di dalamnya. Makin aktif senyawa metabolit sekunder yang dikandung, maka semakin berpotensi tanaman tersebut digunakan dalam pengobatan. Oleh karena itu, penelitian terhadap toksisitas ekstrak kulit jeruk sambal untuk menentukan kebenaran adanya kandungan senyawa metabolit sekunder aktif dalam tanaman masih sangat dibutuhkan agar pemanfaatannya sebagai alternatif pengobatan menjadi lebih maksimal (Lisdawati, 2006).

Salah satu metode awal yang sering dipakai untuk mengamati toksisitas senyawa dan merupakan metode penapisan untuk aktivitas antikanker senyawa kimia dalam ekstrak tanaman berdasarkan metode Meyer adalah Brine Shrimp Lethality Test (BSLT). Metode ini ditujukan terhadap tingkat mortalitas larva udang Artemia salina L. yang disebabkan oleh 
ekstrak uji. Hasil yang diperoleh dihitung sebagai nilai $\mathrm{LC}_{50}$ (letal concentration) ekstrak uji, yaitu jumlah dosis atau konsentrasi ekstrak uji yang dapat menyebabkan kematian larva udang sejumlah 50\% setelah masa inkubasi 24 jam. Senyawa dengan $\mathrm{LC}_{50}<1000 \mu \mathrm{g} / \mathrm{mL}$ dapat dianggap sebagai suatu senyawa aktif.

Berdasarkan uraian di atas peneliti tertarik melakukan suatu penelitian dengan judul Uji Toksisitas Akut Ekstrak Metanol Kulit Buah Jeruk Sambal (Citrus microcarpa Bunge) terhadap Larva Artemia salina L dengan Metode BSLT (Brine Shrimp Lethality Test) untuk mengetahui apakah ekstrak metanol kulit jeruk sambal memiliki sifat sitotoksik dan berapakah nilai $\mathrm{LC}_{50}$ ekstrak metanol kulit jeruk sambal.

\section{METODE PENELITIAN}

Alat dan Bahan

Alat-alat yang digunakan pada penelitian ini adalah ayakan, blender, neraca analitik, batang pengaduk, gelas ukur, toples kaca bertutup, rotary evaporator, gelas beker, $\mathrm{pH}$ universal, pipet tetes, pisau, oven, alumunium foil, vial, kaca pembesar, mikroskop cahaya, lakban hitam, wadah kaca transparan, termometer, dan lampu pijar 40-60 Watt.

Bahan-bahan yang digunakan dalam penelitian ini yaitu kulit jeruk sambal (Citrus microcarpa Bunge), metanol, aquadest, telur Artemia salina Leach, $\mathrm{NaCl}, \mathrm{MgSO}_{4}, \mathrm{KCl}$, $\mathrm{MgCl}_{2}, \mathrm{CaCl}_{2}, \mathrm{NaHCO}_{3}$.

\section{Prosedur Kerja}

\section{Determinasi Tanaman}

Determinasi tanaman dilakukan di Laboratorium Biologi Fakultas Matematika dan Ilmu Pengetahuan Alam, Universitas Tanjungpura. Tujuan dari determinasi ialah untuk menentukan spesies tanaman yang akan digunakan pada penelitian ini.

\section{Pengumpulan dan Pengolahan Sampel}

Buah dibersihkan dan dipisahkan dari kulitnya menggunakan pisau. Kulit kemudian dipotong kecil-kecil, dikeringkan dengan menggunakan oven pada suhu $40^{\circ} \mathrm{C}$ dan dihaluskan menggunakan blender hingga menjadi serbuk dan di ayak menggunakan pengayak mesh 40 .

\section{Pembuatan Ekstrak Metanol Kulit Jeruk Sambal}

Serbuk kulit jeruk ditimbang sebanyak $500 \mathrm{~g}$, lalu dimasukkan kedalam bejana maserasi dengan pelarut metanol dan dimaserasi selama 3x24 jam. Hasil maserasi kemudian disaring. Filtrat hasil maserasi selama tiga hari digabung lalu dievaporasi menggunakan rotary evaporator hingga diperoleh ekstrak pekat.

\section{Pembuatan Air Laut Buatan}

Dibuat $1 \mathrm{~L}$ air laut buatan dengan cara mencampurkan $\mathrm{NaCl}$ sebanyak 5 gram; kalium klorida $(\mathrm{KCl})$ sebanyak 0,2 gram; magnesium sulfat $\left(\mathrm{MgSO}_{4)}\right.$ sebanyak 1,3 gram; magnesium klorida $\left(\mathrm{MgCl}_{2}\right)$ sebanyak 1 gram; kalsium klorida $\left(\mathrm{CaCl}_{2}\right)$ sebanyak 0,3 gram; dan natrium hidrokarbonat $\left(\mathrm{NaHCO}_{3}\right)$ sebanyak 2 gram yang telah terlebih dahulu ditimbang menggunakan timbangan analitik kemudian dilarutkan dengan aquadest sebanyak 1 liter. Khusus untuk $\mathrm{MgSO}_{4}$ sebelumnya telah dilarutkan terlebih dahulu dengan air panas (Mudjiman, 1989).

\section{Penetasan Larva Udang}

Penetasan dilakukan dengan cara menyiapkan wadah untuk menetaskan telur udang. Wadah dibagi menjadi dua bagian, bagian gelap dan terang dengan menyekatnya dan diberi lubang pada sekatan. Kemudian ditambahkan dengan air laut buatan sebanyak $500 \mathrm{~mL}$. Satu ruang dalam wadah tersebut diberi penerangan dengan cahaya lampu 4060 watt agar suhu penetasan tetap terjaga $25^{\circ} \mathrm{C}-31^{\circ} \mathrm{C}$. Sedangkan di ruang sebelahnya 
diberi air laut buatan tanpa penerangan ditutup dengan alumunium foil atau lakban hitam. Artemia salina Leach sebanyak $100 \mathrm{mg}$ terlebih dahulu dicuci yakni ditaburkan dan direndam pada wadah berisi akuadest selama 1 jam, lalu ditiriskan kemudian telur dimasukkan ke dalam wadah yang sudah berisi air laut buatan, dibiarkan selama 2 x 24 jam sampai menetas menjadi nauplii yang matang dan siap digunakan.

\section{Pembuatan Larutan Konsentrasi Sampel Uji}

Ekstrak yang akan diuji dibuat dalam konsentrasi $0 \mu \mathrm{g} / \mathrm{ml} ; 100 \mu \mathrm{g} / \mathrm{ml} ; 250 \mu \mathrm{g} / \mathrm{ml}$; $500 \mu \mathrm{g} / \mathrm{ml} ; 750 \mu \mathrm{g} / \mathrm{ml} ; 1000 \mu \mathrm{g} / \mathrm{ml}$ dalam air laut buatan. Untuk pembuatan larutan stok konsentrasi $1000 \mu \mathrm{g} / \mathrm{ml}$ adalah ekstrak metanol kulit jeruk sambal ditimbang sebanyak $100 \mathrm{mg}$ kemudian dilarutkan dengan $100 \mathrm{ml}$ air laut buatan. Dari larutan induk ini selanjutnya dibuat lagi konsentrasi $750 \mu \mathrm{g} / \mathrm{ml}, 500 \mu \mathrm{g} / \mathrm{ml}, 250 \mu \mathrm{g} / \mathrm{ml}, 100 \mu \mathrm{g} / \mathrm{ml}$ dan 0 $\mu \mathrm{g} / \mathrm{ml}$ dengan cara pengenceran yang dicukupkan dengan air laut buatan hingga $5 \mathrm{ml}$.

\section{Pengujian Toksisitas Ekstrak dengan Metode BSLT}

Disiapkan vial untuk pengujian, untuk masing-masing konsentrasi larutan uji membutuhkan 5 vial dan larutan kontrol sebanyak 5 vial. Dalam 6 kelompok masingmasing terdiri dari 10 ekor larva Artemia Salina dengan replikasi atau pengulangan sebanyak 5 kali. Kelompok 1 (kontrol) diberi air laut sebanyak 5 ml. Kelompok 2 diberi larutan uji ekstrak kulit buah jeruk sambal dengan konsentrasi $100 \mu \mathrm{g} / \mathrm{ml}$. Kelompok 3 diberi larutan uji ekstrak kulit buah jeruk sambal dengan konsentrasi $250 \mu \mathrm{g} / \mathrm{ml}$. Kelompok 4 diberi larutan uji ekstrak kulit buah jeruk sambal dengan konsentrasi 500 $\mu \mathrm{g} / \mathrm{ml}$. Kelompok 5 diberi larutan uji ekstrak kulit buah jeruk sambal dengan konsentrasi $750 \mu \mathrm{g} / \mathrm{ml}$. Kelompok 6 diberi larutan uji ekstrak kulit buah jeruk sambal dengan konsentrasi $1000 \mu \mathrm{g} / \mathrm{ml}$. Masing-masing vial diletakkan di bawah penerangan lampu 4060 watt. Pengamatan dilakukan selama 24 jam terhadap kematian larva kemudian dibandingkan dengan kontrol. Kriteria standar untuk menilai kematian larva Artemia salina yaitu bila larva Artemia salina tidak menunjukkan pergerakan. Dihitung jumlah larva yang mati dengan bantuan kaca pembesar. Jumlah nauplii yang mati dihitung dengan mengurangkan jumlah total nauplii pada tiap konsentrasi dengan jumlah nauplii yang masih hidup (Kurniawan, 2012; Oratmangun, 2014).

\section{Analisis Data}

Teknik analisa yang digunakan untuk uji mortalitas larva udang yaitu berdasarkan nilai Lethal Concentration $50 \%\left(\mathrm{LC}_{50}\right)$ menggunakan metode probit. Caranya dengan menentukan nilai probit dari \% kematian tiap kelompok hewan uji.

$\%$ kematian dihitung dengan rumus :

$$
\% \text { kematian }=\frac{\text { jumlah larva mati }}{\text { jumlah larva total awal }} \times 100 \%
$$

Namun apabila pada kontrol ada yang mati, \% kematian ditetapkan dengan rumus :

$\%$ kematian $=\frac{\text { jumlah larva yang mati pada uji-jumlah larva yang mati pada kontrol }}{\text { jumlah larva uji mula-mula pada larutan uji }} \times 100 \%$

Menentukan persamaan garis lurus hubungan antara nilai probit dengan log dosis, $\mathrm{Y}=\mathrm{mX}+\mathrm{b}$, dimana $\mathrm{Y}=$ angka probit $\operatorname{dan} \mathrm{X}=\log$ konsentrasi

\section{HASIL DAN PEMBAHASAN}

Penelitian ini menggunakan kulit jeruk sambal yang telah dideterminasi di Laboratorium Biologi Fakultas Matematika dan Ilmu Pengetahuan Alam, Universitas Tanjungpura. Hasil determinasi menunjukkan tanaman tersebut termasuk dalam spesies Citrus microcarpa Bunge. 
Brine Shrimp Lethality Test (BSLT) merupakan salah satu metode uji toksisitas yang banyak digunakan dalam penelusuran senyawa bioaktif yang bersifat toksik dari bahan alam terhadap larva udang. Keunggulan dari metode BSLT ini adalah mudah dilakukan, murah dan tidak memerlukan waktu yang lama (Kristanti, dkk, 2008 dan Priyanto, 2010). Oleh karena itu, kemampuan untuk mematikan larva udang dapat digunakan sebagai uji pendahuluan yang cepat dan sederhana untuk mengetahui bioaktivitas suatu senyawa secara in vivo. Uji toksisitas akut dilakukan terhadap larva Artemia salina Leach yang berusia 24 hingga 48 jam atau disebut nauplii pada media air laut buatan. Pada pengujian toksisitas Artemia salina yang digunakan ialah yang berada pada tahap nauplii atau tahap larva. Hal ini dikarenakan Artemia salina pada tahap nauplii sangat mirip dengan sel manusia (Oratmangun dkk., 2014).

Artemia salina memiliki respon yang sama dengan mamalia sehingga senyawa maupun ekstrak yang memiliki aktivitas pada sistem tersebut dapat terdeteksi, misalnya DNA-dependent RNA polymerase pada Artemia salina serupa dengan ouabaine-sensitive $\mathrm{Na}^{+}$dan $\mathrm{K}^{+}$dependen ATPase pada mamalia (Solis dkk., 1993). Disamping mudah diperoleh, Artemia salina L. memiliki beberapa keunggulan diantaranya perkembangbiakannya cepat, harganya murah, metode percobaannya mudah, untuk uji ini hanya memerlukan sampel sedikit (sangat sesuai untuk uji aktivitas suatu senyawa isolasi), tidak memerlukan laboratorium khusus dan hasilnya dapat dipercaya (Kristanti dkk., 2008). Derajat $\mathrm{pH}$ dari air laut buatan tersebut adalah 9. Hal ini dikarenakan apabila $\mathrm{pH}$ dibawah 8 dapat mengakibatkan kematian larva (Kristanti dkk., 2008).

Berdasarkan hasil penelitian didapatkan data kematian larva Artemia salina $\mathrm{L}$ setelah diberi seri konsentrasi ekstrak selama 24 jam. Kematian larva pada uji ini disajikan dalam tabel I.

Tabel I. Hasil Kematian Larva setelah 24 Jam

\begin{tabular}{cccccccccc}
\hline $\begin{array}{c}\text { Konsentrasi } \\
\text { Larutan Uji } \\
(\boldsymbol{\mu g} / \mathbf{m L})\end{array}$ & $\begin{array}{c}\text { Log } \\
\text { Konsentrasi }\end{array}$ & $\mathbf{1}$ & $\mathbf{2}$ & $\mathbf{3}$ & $\mathbf{4}$ & $\mathbf{5}$ & $\begin{array}{c}\text { Rata-rata } \\
\text { Kematian } \\
\text { Larva }\end{array}$ & $\begin{array}{c}\text { \% } \\
\text { Kematian } \\
\text { Larva }\end{array}$ & $\begin{array}{c}\text { Nilai } \\
\text { Probit }\end{array}$ \\
\hline 0 & 0 & 0 & 0 & 0 & 0 & 0 & 0 & 0 & 0 \\
\hline 100 & 2 & 3 & 2 & 2 & 3 & 5 & 3 & 30 & 4,48 \\
\hline 250 & 2,39 & 4 & 6 & 7 & 5 & 4 & 5,2 & 52 & 5,05 \\
\hline 500 & 2,69 & 6 & 7 & 5 & 7 & 8 & 6,6 & 66 & 5,41 \\
\hline 750 & 2,87 & 9 & 9 & 7 & 8 & 8 & 8,2 & 82 & 5,92 \\
\hline 1000 & 3 & 8 & 9 & 10 & 10 & 9 & 9,2 & 92 & 6,41 \\
\hline
\end{tabular}

Selanjutnya dilakukan perhitungan $\mathrm{LC}_{50}$ dengan metode analisis probit. Hasil diolah menggunakan Ms. Excel untuk mencari regresi linier berdasarkan grafik garis. Dari gambar 1 didapatkan persamaan $\mathrm{y}=\mathrm{mx}+\mathrm{b}$ dan nilai $\mathrm{R}$ square $\left(\mathrm{R}^{2}\right)$. Adapun grafik hubungan antara $\log$ konsentrasi dengan probit kematian larva disajikan pada gambar 1.

Senyawa dianggap memiliki potensi toksik atau bersifat sitotoksik jika memiliki lethal concentration $50\left(\mathrm{LC}_{50}\right)$ kurang dari $1000 \mu \mathrm{g} / \mathrm{ml}$ dan dapat dianggap sebagai suatu senyawa aktif. Pada hasil penelitian didapatkan bahwa nilai $\mathrm{LC}_{50}$ dengan regresi linear $M s$. Excel adalah 234,42 $\mu \mathrm{g} / \mathrm{ml}$. Dengan kata lain Ekstrak metanol kulit jeruk sambal bersifat sitotoksik terhadap larva Artemia salina Leach. Hal ini disebabkan oleh adanya senyawa aktif yang terkandung dalam ekstrak metanol kulit jeruk sambal dalam bentuk metabolit sekunder yaitu flavonoid, dan alkaloid. Karena sifat sitotoksik dari senyawa-senyawa tersebut, dengan konsentrasi tertentu dapat membunuh larva Artemia salina Leach. 


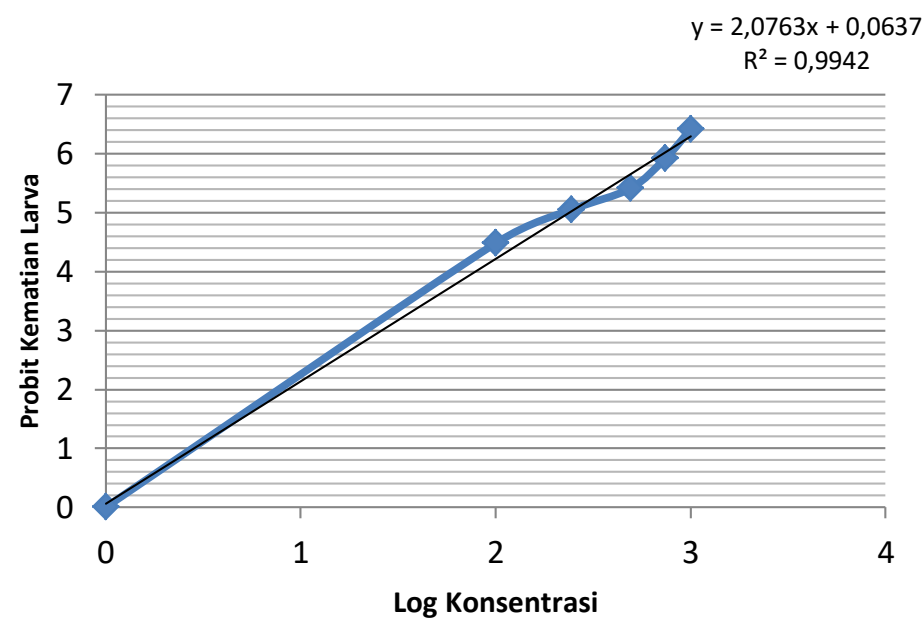

Gambar 1. Grafik Hubungan antara Log Konsentrasi dengan Nilai Probit terhadap Kematian Larva

Kemungkinan terjadinya difusi zat dari lingkungan yang mempengaruhi metabolisme dalam tubuh Artemia salina ini dikarenakan Artemia salina yang memiliki membran kulit yang sangat tipis (Tekha, 2015). Mekanisme kematian larva Artemia salina Leach berhubungan dengan fungsi senyawa alkaloid dan flavonoid yaitu menghambat daya makan larva (antifedant). Cara kerja senyawa-senyawa tersebut adalah dengan bertindak sebagai stomach poisoning atau racun perut. Alat pencernaan larva akan terganggu apabila senyawa-senyawa ini masuk ke dalam tubuh larva. Senyawa ini juga menghambat larva gagal mendapatkan stimulus rasa, sehingga tidak mampu mengenali makanannya sehingga larva mati kelaparan (Rita dkk., 2008 dalam Putri dkk, 2012).

Selain itu apabila nilai $\mathrm{LC}_{50}$ lebih rendah dari $1000 \mu \mathrm{g} / \mathrm{ml}$ maka bahan tersebut berpotensi sebagai agen antikanker (Rahayu, 2013., Kristanti dkk., 2008). Mekanisme kerja flavonoid dalam menghambat pertumbuhan larva diduga dengan cara menghambat tranduksi sinyal ke inti melalui inhibisi protein kinase sehingga menghambat proliferase sel kanker dan menghambat pertumbuhan suatu keganasan dengan menginhibisi reseptor tirosin kinase yang berperan dalam meningkatkan pertumbuhan keganasan (Reskianingsihm dalam Supriningrum, 2016).

Semakin tinggi konsentrasi ekstrak maka semakin tinggi pula jumlah kematian larva. Hal ini sesuai dengan Harborne (1994), yang menyebutkan bahwa semakin tinggi konsentrasi ekstrak maka sifat toksiknya akan semakin tinggi (Supriningrum, 2016).

\section{KESIMPULAN}

Berdasarkan hasil penelitian tentang uji toksisitas akut ekstrak metanol kulit jeruk sambal (Citrus microcarpa Bunge) terhadap larva Artemia salina L dengan metode BSLT dapat disimpulkan bahwa ekstrak metanol kulit jeruk sambal bersifat sitotoksik terhadap larva Artemia salina Leach dengan metode BSLT dan nilai LC $_{50}$ ekstrak metanol kulit jeruk sambal terhadap larva Artemia salina Leach dengan metode BSLT adalah 234,42 $\mu \mathrm{g} / \mathrm{ml}$.

\section{UCAPAN TERIMAKASIH}

Peneliti mengucapkan terimakasih kepada Akademi Farmasi Yarsi Pontianak atas semua kontribusinya selama penelitian berlangsung. 


\section{DAFTAR PUSTAKA}

Cheong MW. 2013. Chemical Components and Aromatic Profiles of Citrus and Coffe in Asia. Thesis. Department of Chemistry. National University of Singapore. Page 238

Jamal, Y., Praptiwi., dan Andria, A. 2000. Komponen Kimia dan Efek Antibakteri Minyak Atsiri Kulit Buah dan Daun Jeruk Kasturi (Citrus microcarpa Bunge). Majalah Farmasi Indonesia 11(2) 77-85

Kristanti, A N., Nanik, S. A., Mulyadi, T., dan Bambang, K. 2008. Buku Ajar Fitokimia. Cetakan I. Airlangga University Press : Surabaya

Kurniawan, H., Nera U.P., dan Inarah F. 2012. Uji Toksisitas Akut Ekstrak Metanol Daun Kesum (Polygonum minus Huds) terhadap Larva Artemia salina Leach dengan Metode Brine Shrimp Lethality Test (BSLT). Skripsi. Program Studi Farmasi Fakultas Kedokteran dan Ilmu Kesehatan, Universitas Tanjungpura : Pontianak.

Lisdawati, V., Sumali, W., dan I Broto, S.K. 2006. Brine Shrimp Lethality Test (BSLT) dari Berbagai Fraksi Ekstrak Daging Buah dan Kulit Biji Mahkota Dewa (Phaleria macrocarpa). Bul. Penel. Kesehatan, Vol. 34 No. 3, Tahun 2006 111-118

Mudjiman, A. 1989. Udang Renik Air Asin (Artemia salina). Jakarta : Bhratara

Oratmangun, S.A., Fatimawali., dan Widdhi, B. 2014. Uji Toksisitas Ekstrak Tanaman Patah Tulang (Euphorbia tirucalli L.) Terhadap Artemia salina dengan Metode Breine Shrimp Lethality Test (BSLT) Sebagai Studi Pendahuluan Potensi Anti Kanker. Jurnal Ilmiah Farmasi UNSRAT Vol 3. No.3. Agustus 2014

Priyanto. 2010. Toksikologi, Mekanisme, Terapi Antidotum, dan Penilaian Risiko. Cetakan II. Leskonfi : Depok

Putri, Mukti K., Delianis, P., dan Ocky, K.R. 2012. Uji Fitokimia dan Toksisitas Ekstrak Kasar Gastropoda (Telescopium telescopium) terhadap Larva Artemia salina. Journal of Marine Research. Vol 1, No. 2

Sibilang A, Pemsi M.W, Juliatri. 2017. Uji Air Perasan Jeruk Kesturi (Citrus microcarpa Bunge) Terhadap Perubahan Warna Resin Komposit yang direndam dalam Larutan Kopi. Jurnal; e-GIGI (eG), Vol 5 Nomor 1

Solis, P. N., Wright, C. W., Anderson, M. M., Gupta, M. P., \& Phillipson, J. D. (1993). A microwell cytotoxicity assay using Artemia salina (brine shrimp). Planta medica, 59(03), 250-252

Supriningrum, R., Sapri., dan Vici, A.P. 2016. Uji Toksisitas Akut Ekstrak Etanol Akar KB (Coptosapelta tomentosa Valeton ex K.Heyne) dengan Metode Brine Shrimp Lethality Test (BSLT). Jurnal Ilmiah Manuntung, 2(2),161-165, 2016

Tekha, K.N., Erwin, A., dan Rudi, K. 2015. Uji Toksisitas Ekstrak Kelopak Jantung Pisang Kepok (Musa Paradisiaca Linn.) dengan Metode BSLT (Brine Shrimp Lethality Test). Jurnal Kimia Mulawarman Volume 13 Nomor 1

Wulandari, M., Nora, I., dan Gusrizal. 2013. Aktivitas Antioksidan Ekstrak n-Heksana, Etil Asetat dan Metanol Kulit Buah Jeruk Sambal (Citrus microcarpa Bunge). JKK, tahun 2013 volume 2(2) hal 90-94 
